IZA DP No. 6969

Socioeconomic Assimilation and Wealth Accumulation of Migrants in Australia

Matias Vaira-Lucero

Daehoon Nahm

Massimiliano Tani

October 2012 


\title{
Socioeconomic Assimilation and Wealth Accumulation of Migrants in Australia
}

\author{
Matias Vaira-Lucero \\ Macquarie University \\ Daehoon Nahm \\ Macquarie University \\ Massimiliano Tani \\ Macquarie University \\ and IZA
}

\section{Discussion Paper No. 6969 \\ October 2012}

\author{
IZA \\ P.O. Box 7240 \\ 53072 Bonn \\ Germany \\ Phone: +49-228-3894-0 \\ Fax: +49-228-3894-180 \\ E-mail: iza@iza.org
}

Any opinions expressed here are those of the author(s) and not those of IZA. Research published in this series may include views on policy, but the institute itself takes no institutional policy positions. The IZA research network is committed to the IZA Guiding Principles of Research Integrity.

The Institute for the Study of Labor (IZA) in Bonn is a local and virtual international research center and a place of communication between science, politics and business. IZA is an independent nonprofit organization supported by Deutsche Post Foundation. The center is associated with the University of Bonn and offers a stimulating research environment through its international network, workshops and conferences, data service, project support, research visits and doctoral program. IZA engages in (i) original and internationally competitive research in all fields of labor economics, (ii) development of policy concepts, and (iii) dissemination of research results and concepts to the interested public.

IZA Discussion Papers often represent preliminary work and are circulated to encourage discussion. Citation of such a paper should account for its provisional character. A revised version may be available directly from the author. 


\section{ABSTRACT \\ Socioeconomic Assimilation and Wealth Accumulation of Migrants in Australia}

This paper investigates to what extent the wealth accumulation of immigrants is explained by their degree of assimilation, defined as the immigrants' capacity to become more similar over time to the local people in terms of their norms, values, behaviours, and socioeconomic characteristics. The existing practice to measure assimilation is the use of a timedimensioned variable like years since migration, which reflects the individual's adaptation to the host country through the implied acquisition of relevant skills and experience. We complement this approach by defining assimilation on the basis of migrants' subjective assessments of integration within the community. To do so, we exploit the rich information collected by the Household Income and Labour Dynamics in Australia Survey (HILDA). In particular, we explore the possible relationship between migrants' savings and assimilation estimating several models, from a pooled OLS to panel data models such as random effect and population average. We find that assimilation has a significant positive effect on wealth accumulation, but in different degrees depending on migrants origins and the type of assets. Understanding migrants' wealth and their perceived degree of assimilation is relevant to understand the supply of domestic savings and their variability. It also carries policy implications on what could be done to affect migrants' sense of assimilation and connected economic behaviour.

JEL Classification: D31

Keywords: precautionary savings, net worth, uncertainty, migrants' assimilation

Corresponding author:

Massimiliano Tani

Department of Economics

Macquarie University

NSW 2109

Australia

E-mail: max.tani@mq.edu.au 


\section{INTRODUCTION}

The saving behaviour of immigrants has received increased attention over the past decade, especially as immigrants have remitted larger amounts of funds to their home countries, often enhancing consumption, investment and the overall development prospects of their countries of origin. The growing attention on remittances however has not been matched by a complementary stream of research on what immigrants do with their savings in the host countries, if anything. Yet, immigrants' saving may be a considerable, valuable, and possibly under-used souce of a host country's domestic supply of savings.

Saving is likely to depend on migrants' perception of their integration and future prospects in the host country, amongst others. The more immigrants feel at home in the country of destination, having children and grandchildren and feeling integrated, the less one would expect the feel of uncertainty about living in a different country from that of birth, and, possibly, a different allocation of wealth between more (illiquid) and less (liquid) assets: is this the case? Does migrants' socioeconomic assimilation affect their wealth accumulation patterns, if at all? Is there a country of origin effect?

We address these questions by studying the relationship between the socioeconomic assimilation of migrants and their wealth accumulation patterns. To do so, we first need review existing approaches to 'assimilation' and its meaning. The assimilation of immigrants has been typically studied in terms of differences in labour market outcomes (wages, employment) and speed of convergence to natives' level (Antecol, 2006; Borjas, 1985; B. Chiswick, 1978; Duncan, 2008). The literature however has no uniform definition of assimilation (Borjas, 1999), and has grappled with measures that include linguistic or subjective assessment (e.g. Dustmann, 1997). We contribute to the existing debate by exploiting a subjective measure of assimilation provided by migrants in a large longitudinal survey. Furthermore, we want to test if the relationship between assimilation and wealth 
accumulated for precautionary reasons differs by country of origin (e.g. Hatton, 1997). To do so we distinguish migrants from English (ESC) and non-English speaking countries (NESC).

The empirical analysis is based on the Household Income and Labour Dynamics in Australia (HILDA) survey. This asks individuals' perceptions about being part of the local communities and how satisfied/dissatisfied respondents are with it.

We find that migrants who settle in a new land tend to save or accumulate wealth differently from natives, and adjust their patterns as they feel more assimilated or integrated into the new culture and customs. We also find that migrants from non-English speaking backgrounds save differently than those originated from English speaking countries due to the uncertainties related to the process of assimilation in a country where the language is not their mother tongue.

Despite the vast literature on assimilation and its labour market implications, understanding assimilation in a broader sense is crucial to explain the reasons behind the behavioural differences in wealth accumulation between migrants and natives and among immigrants from different countries of origin. Immigrants' savings matter not only for remittances and development at home, but also for contributing to capital formation in the host countries, especially when the foreign-born constitute a substantial fraction of the host country's population as in Australia.

The rest of the paper is organized as follows. A brief literature review of migrants' savings and their economic assimilation is presented in Section 2, while a description of the data is presented in Section 3. The empirical strategy is discussed in Section 4, and the estimation results are analysed in Section 5. In the last section we draw some policy conclusions.

\section{LITERATURE REVIEW}


The interest in migrants' assimilation has increased in the last thirty years and focused on measuring differences in labour market outcomes between foreigners and natives, and how quickly foreigners close income gaps for given individual characteristics. Chiswick (1978) pioneered this literature in his work on immigrants' wage assimiliation in the US. His result that immigrants adjust to the US market, and their earnings grows rapidly with time since migration, estimated in ten to fifteen years the time in which, on average, an immigrant's earning/wages reaches levels to that of an equivalent US-born individual. A vast literature followed, measuring assimilation in terms of income gap or probability of employment between immigrants and natives, in several countries (Antecol, 2006; Borjas, 1985; B. Chiswick, 1978; Duncan, 2008).

Besides objective monetary differences, some researchers have developed alternative measures of assimilation. In some cases these measures are 'objective', as in the case of Chiswick and Miller (2011), who make use of the "linguistic distance" of the migrants" mother tongue from English. Their findings show that migrants from non-English speaking countries experience positive assimilation as their earnings increase with the duration of residence in the host country (the US), but this positive effect is more intense the more their language is distant from English. Intiguingly, they find a negative effect from duration of residence (negative assimilation) when the migrants originate from English speaking countries.

In other cases, the measure of assimilation relies on self-assessment from ad hoc survey questions. For instance, Dustmann (1997) explores social assimilation using the answers from a question in the German Socioeconomic Panel Survey (GSOEP) which asks migrants "how German they feel". Interpreting the question as an indicator of an immigrant's feeling of integration/identity in Germany, Dustmann finds that migrants' assimilation depends on time spent in the host country as well as subjective feelings of national identity (social 
assimilation) such as education and fluency in the host country's language. In contrast, the age of immigrants at entry emerges as a negative contributor to integration. In line with Dustmann (1997), we use the idea of assimilation as a broader concept not only associated to time spent in the host country but also to other aspects of a migrant's life in the new society, which involve major changes, pressures and uncertainties that are likely to affect their economic decisions.

We also apply assimilation to native-migrants differences in wealth to contribute to the rather limited amount of research on the wealth accumulation (savings) patterns of migrants. Existing work has suggested that natives and immigrants may have different motives and incentives to save (Amuedo-Dorantes, 2002; Cobb-Clark \& Hildebrand, 2009; Doiron \& Guttmann, 2009). Amuedo-Dorantes (2002) finds significant differences in the accumulation of precautionary savings by young migrants in the US when compared to natives, measuring savings as the ratio of net wealth to permanent income. Precautionary savings increase with income uncertainty but only for natives and, in the case of migrants, the coefficient was only significant for savings in the form of financial wealth. Cobb-Clark and Hildebrand (2009) analyse the assets' portfolio of natives and migrants in Australia according to their marital status, finding a significant wealth advantage of single immigrants over native-born individuals. In contrast, immigrant-only couples accumulate less wealth on average than native-born and mixed couples. In the same line of research, Doiron and Guttmann (2009) study the wealth distribution of migrants and Australian born households using quantile regressions, finding that migrants have significantly less wealth than their local counterparts all along the distribution.

In our approach we complement the theoretical framework of Schaeffer (1995), who frames the role play by the degree of assimilation on the decisions of immigrants about work and savings. The model describes an inter-temporal utility maximization where the utility 
function of immigrants differs from that of natives because it includes non-monetary costs (psychic, stress) that reduce the pleasure derived from consuming leisure and commodities in a place (the host country) where friends and family are absent. In this model, migrants increase work and savings efforts and reduce the consumption of leisure proportionally with lower levels of social assimilation into the host society. Furthermore, migrants from countries with a greater cultural distance from the destination country are predicted to work and save more since they are likely to have lower assimilation values. Our study complements Schaeffer's (1995) theoretical model in that we use a measure of migrants' self-assessment of assimilation as an explanatory variable for their wealth accumulation and can test whether savings from migrants of non-English speaking countries respond differently to the feeling of assimilation vis-à-vis those of English speaking immigrants to Australia, who share the same language of the host society.

\section{DATA AND DESCRIPTIVE STATISTICS}

The Household Income and Labour Dynamics in Australia Survey (HILDA) collect information about economic and subjective well-being, labour market dynamics and family dynamics. The quality of HILDA's wealth data has been assessed by Headey et al. (2005) through comparisons with the national aggregates compiled by the ABS (Australian Bureau of Statistics) and regular estimates by the RBA, resulting in a very accurate wealth data collection which estimates about $93 \%$ of the ABS results.

The use of HILDA has a great advantage given by the longitudinal characteristic of the data which makes possible to follow the same individuals over time and reduce the possibility of heterogeneity bias in the estimations. In contrast, one of the drawbacks of this database is that attrition appears to be non-random, meaning that persons that exit from the panel have characteristics that are systematically different from those who remain. Even though this 
problem is particularly marked with respect to some characteristics such as country of birth which is core information for our study, the dataset has been adjusted for attrition through the use of sample weights (Summerfield, 2010), reducing significantly the possibility of biases in our results and conclusions.

Our interest is focused on individuals between 25 and 64 years of age and the three periods $(2002,2006$ and 2010) that contain data on household wealth and its composition. The total sample after accounting for missing values comprises approximately 18,295 respondent persons in 2002, 17,453 in 2006 and 17,855 in 2010. When refining the data, constructing a balanced panel and accounting for the endowment of wealth using the first wave available as a proxy variable, the total of 53,603 individuals reduces to $17,606(8,803$ individuals in each of the waves).

Table 1 reports the main variables used in the empirical analysis, by nationality group. These are age, gender, marital status, disposable income, number of household members, level of education, place of residency, years since migration, labour market experience and a dummy for satisfaction with community participation which in turn represents the migrant subjective assessment of assimilation. While migrants as a group accumulate $28 \%$ of their assets on the financial category, if they are from English-speaking countries are clearly more inclined towards financial assets with $33.4 \%$ compared to $22 \%$ for the group of non-English speaking countries of birth. In addition, migrants from NESC appear to have 5\% more debt than the ESC subsample whose debt is $13 \%$ of the total value of assets.

There are also some differences in demographic characteristics between the two groups, being the most important ones in terms of age, time spent in Australia, disposable income and household composition. Both groups have similar education and marital status with most of the migrants (from NESC or ESC) being married or in a de-facto relationship. In terms of education and household composition, between 50 and $60 \%$ of the migrants have a tertiary 
degree or higher, and the percentage of migrants households from NESC that have children younger than 14 years old is significantly higher than households from ESC.

Two variables in the model capture the degree of migrants' assimilation: the time spent in the host country and a self-reported feeling (scale of agreement/disagreement) regarding their degree of participation in the community. Most of the literature interprets the regression coefficient for "time spent in the host country" as an indicator of the effect of migrants" assimilation on net wealth but since they use cross-sectional data, it may also reflect a decline in the skills across different cohorts of migrants (Borjas, 1995). Thanks to the panel features of HILDA we can identify more precisely the effect of assimilation on migrants' wealth accumulation patterns with controls for individual unobserved heterogeneity.

We use a '*' to indicate statistically significantly different means using the t-test on the equality of means for the relevant groups. 
Table 1 : Descriptive Statistics

\begin{tabular}{|c|c|c|c|c|c|c|c|}
\hline \multirow[b]{2}{*}{ Variable } & & \multicolumn{2}{|c|}{ NATIVES } & \multicolumn{2}{|c|}{ MIGRANTS ESC } & \multicolumn{2}{|c|}{ MIGRANTS NESC } \\
\hline & & Mean & S.D. & Mean & S.D. & Mean & S.D. \\
\hline rhwnet & Hous ehold Net Worth (\$'OOO) & 422.07 & 673.30 & $462.28 * *$ & 705.66 & $379.87 * * *$ & 614.14 \\
\hline rhwtotfin & Household Total Financial Assets ( $\$$ & $158.40^{* *}$ & 295.25 & $176.36 * * *$ & 320.40 & $117.78 * *$ & 231.47 \\
\hline rhwtotnfin & Household Total Non-Financial Assets (\$'000) & $354.17^{* *}$ & 569.03 & $379.02 *$ & 592.40 & 368.79 & 549.74 \\
\hline rhwtotdebt & Household Total Debt (\$'OOO) & $92.21 * * *$ & 172.17 & 93.67 & 164.85 & $107.26 * * *$ & 186.97 \\
\hline rdispinc & Disposable Income (\$'000) & $24.18^{*}$ & 19.85 & $26.18^{* * *}$ & 22.71 & $21.27^{* * *}$ & 19.78 \\
\hline hgage & Age in years & $43.83 * * *$ & 10.69 & $47.78 * * *$ & 10.03 & $46.26 * * *$ & 10.48 \\
\hline male & Gender $($ male $=1)$ & 0.46 & 0.50 & $0.50 * * *$ & 0.50 & $0.42 * * *$ & 0.49 \\
\hline married & Marital Status (married or defacto $=1$ ) & $0.72 * * *$ & 0.45 & $0.77 * * *$ & 0.42 & $0.79 * * *$ & 0.41 \\
\hline dkids & Household with children younger than 14 & $0.40 * * *$ & 0.49 & $0.33 * * *$ & 0.47 & 0.40 & 0.49 \\
\hline dedhigh & Education (Terciary or higher degree $=1$ ) & $0.59 * * *$ & 0.49 & $0.65 * * *$ & 0.48 & 0.61 & 0.49 \\
\hline ysm & Years in Australia & & & $29.27^{* * *}$ & 13.28 & $25.07^{* * *}$ & 14.29 \\
\hline commsatis & Satisfacction with community participation & $0.74 * * *$ & 0.43 & $0.71 * *$ & 0.45 & $0.69 * * *$ & 0.46 \\
\hline dremote & Resident of remote area & $0.14 * * *$ & 0.36 & $0.10 * * *$ & 0.31 & $0.04 * * *$ & 0.22 \\
\hline dqld & Queensland resident & $0.22 * * *$ & 0.42 & 0.22 & 0.41 & $0.11 * * *$ & 0.32 \\
\hline dsa & South Australia resident & $0.09 * * *$ & 0.30 & 0.09 & 0.29 & $0.07 * * *$ & 0.26 \\
\hline dact & Canberra resident & $0.01 * * *$ & 0.13 & $0.02 * * *$ & 0.16 & $0.02 * * *$ & 0.16 \\
\hline dnt & Northern Territory resident & $0.006 * * *$ & 0.08 & $0.01 * * *$ & 0.12 & $0.01 * * *$ & 0.11 \\
\hline dvic & Victoria resident & 0.24 & 0.43 & $0.18 * * *$ & 0.39 & $0.30 * * *$ & 0.46 \\
\hline dtas & Tasmania resident & $0.03 * * *$ & 0.18 & 0.03 & 0.16 & $0.008^{* * *}$ & 0.09 \\
\hline dnsw & New South Wales resident & $0.28 * * *$ & 0.45 & $0.26 * * *$ & 0.44 & $0.36 * * *$ & 0.48 \\
\hline \multicolumn{2}{|c|}{ Observations } & \multicolumn{2}{|l|}{15109} & \multicolumn{2}{|l|}{2066} & \multicolumn{2}{|l|}{2312} \\
\hline \multicolumn{8}{|c|}{$* * * \mathrm{p}<0.01, * * \mathrm{p}<0.05, * \mathrm{p}<0.1$} \\
\hline $\begin{aligned} & \text { Notes: } \text { All h } \\
& \text { Fina } \\
& \text { Non- } \\
& \text { Tota }\end{aligned}$ & $\begin{array}{l}\text { ousehold wealth values and disposable income } \\
\text { ncial Wealth includes: bank deposits, life insur } \\
\text {-Financial Wealth includes: housing, collectibl } \\
\text { I Debt includes: housing, credit card, HECS and }\end{array}$ & $\begin{array}{l}\text { ne deflate } \\
\text { nce, super } \\
\text {, business } \\
\text { ther debts }\end{array}$ & $\begin{array}{l}d \text { by the } \\
\text { annuati } \\
\text { and ver }\end{array}$ & ust funds & quity a & inves tmer & \\
\hline
\end{tabular}

The key identifying variable for our analysis is 'commsatis', which represents the selfreported feeling of community participation. This is based on a question from the Continuing Person Questionnaire of HILDA Survey (question K61) asking individuals to indicate "the level of satisfaction experienced with feeling part of their local community". It uses a scale from 0 to 10 where zero means totally dissatisfied, five is a neutral feeling and ten reveals an individual who is totally satisfied.

Table 2 shows the proportion of individuals in each category of a new dummy variable (satisfied $=1$ correspond to responses from 0 to 5 in the previous scale) for all Australians- 
born and for the subsamples of migrants from non-English speaking (NESC) and English speaking (ESC) countries.

Table 2 Community Participation Feeling (Dummy=1 satisfied, zero otherwise)

\begin{tabular}{|c|c|c|c|c|c|c|}
\hline & \multicolumn{2}{|c|}{ NATIVES } & \multicolumn{2}{|c|}{ NESC MIGR } & \multicolumn{2}{|c|}{ ESC MIGR } \\
\hline & Cases & Percent & Cases & Percent & Cases & Percent \\
\hline dissatisfied & 5140 & 25.13 & 951 & 30.08 & 782 & 28.09 \\
\hline satisfied & 15,317 & 74.87 & 2,211 & 69.92 & 2,002 & 71.91 \\
\hline Sum & $20457^{* * *}$ & 100 & $3162 * * *$ & 100 & $2784 * *$ & 100 \\
\hline
\end{tabular}

The definition of net wealth used in this study is obtained as total assets minus total liabilities following the model presented on the HILDA User Manual Release 10. Assets are classified into two categories: financial assets which include bank deposits, life insurance, 'superannuation' (Australia's pension contributions), trust funds, equity and cash investments and non-financial assets as housing, collectibles, business and vehicles. There are also different types of liabilities which HILDA classified as related to housing, credit card, HECS and other debts.

Table A1 in the Appendix shows the evolution over time of the mean values for each of the components of net worth and compares the magnitude of the differences between wealth of migrants from English-speaking countries (ESC) and from non-English speaking countries (NESC). For instance, there is a remarkable difference between the financial assets accumulated by both groups, particularly those assets classified as "equity investment" or "superannuation" where migrants from ESC more than double the amount kept by migrants from non-English speaking background. Moreover, with reference to debt, the difference between both groups appears to be declining over time, showing migrants from ESC with more debt than NESC migrants during 2002, but reverted in 2006 and 2010 when the latter group shows $10.2 \%$ and $18.8 \%$ higher debt than the former. 


\section{EMPIRICAL APPROACH}

Several are the reasons to save but the most important are to finance expenditures after retirement and to be prepared in case of unexpected shocks (precautionary motives). Households are subject to different sources of risk and a way to self-insure against them is to accumulate a buffer stock of wealth (Carroll, 1997). The goal of the empirical estimation is to analyse the relationship between the wealth accumulated by migrants and their degree of assimilation into the host society, considering that less assimilated migrants may face higher uncertainties in the host country and therefore they would adjust their wealth accumulation patterns accordingly as a way to save for precautionary reasons.

Given the longitudinal characteristics of the data, it seems reasonable to perform the analysis using one of the panel methods available for linear models. The HILDA survey follows the same individuals over time and collects information since 2001 (10 years), but the wealth variables have only been collected for three periods (2002, 2006 and 2010). This can be a limitation to the econometric models and the robustness of the estimations. In addition, to analyse and compare the wealth accumulation patterns of migrants and Australians-born over time, we need a variable that indicates the endowment of wealth that migrants brought to Australia by the time of entry. Unfortunately the HILDA survey does not have that information. As a result, we decided to use the first year of data with information regarding the wealth level (year 2002) as a proxy variable for the initial endowment carried by immigrants when they moved to Australia. This forces us to lose one year of data from the panel, resulting in a panel with only two waves of data on wealth (years 2006 and 2010) and a reduced sample size from 26,409 observations to 17,606 . 
The literature suggests different econometric models to run estimations when the dataset presents longitudinal characteristics with a big number of observations and only a few periods (short panel). The models we have considered are: fixed effect (FE), random effect (RE) and, population average (PA or FGLS). There is also the possibility of estimating the model using a pooled OLS estimator bearing in mind that we have only two periods of data and any time-specific effect can be considered as fixed and include it as time dummies in the regressors.

Our initial approach is to use a panel technique to eliminate the possible bias due to unobserved individual heterogeneity. Our preferred choice is a random effect (RE) rather than a fixed effect model (FE), since the main focus of this study is a time-invariant explanatory variable related to country of birth. This would be swiped off in a fixed effect model, as the OLS estimation is performed on mean-differenced data resulting in zeros for those variables that are time-invariant, such as the country of birth.

On the other hand, the RE model makes a strong assumption in that individual-specific effects are purely random and uncorrelated with the regressors. This could lead to inconsistent estimations if the appropriate model is instead the FE. As we have only two periods of data in our panel, it is also reasonable to use a pooled OLS model and include a time dummy variable for the second year of data (2010) together with the relevant interactions with the other explanatory variables.

The RE model can be specified as follows (Cameron, 2010): $y_{i t}=x_{i t}^{\prime} \beta+\left(\alpha_{i}+\varepsilon_{i t}\right)$ with $\alpha_{i} \sim\left(\alpha, \sigma_{\alpha}^{2}\right)$ and $\varepsilon_{i t} \sim\left(0, \sigma_{\mu}^{2}\right)$ Then the combined error $\mu_{i t}=\alpha_{i}+\varepsilon_{i t}$ is correlated over time (t) for a given individual $i$ with $\operatorname{Cor}\left(\mu_{i t}, \mu_{i s}\right)=\sigma_{\alpha}^{2} /\left(\sigma_{\alpha}^{2}+\sigma_{\varepsilon}^{2}\right)$ for all $\mathrm{s} \neq \mathrm{t}$ and consequently is not independent and identically distributed (i.i.d). 
The technique to estimate this RE model is the feasible generalized least square (FGLS), which relies on the idea that if the variance matrix for the error term is known it is then possible to transform the data such that the resulting errors become i.i.d. As the error variance matrix in the RE model is in practice unknown, one needs to assume a structure that describes how the errors deviate from i.i.d errors to obtain a consistent estimation of the matrix. That estimation may be used to transform the data and generate observations with i.i.d. errors (Baum, 2006).

The RE estimator obtained by OLS estimation in the following transformed model is:

$$
\left(y_{i t}-\hat{\theta}_{i} \overline{y_{i}}\right)=\left(1-\hat{\theta}_{i}\right) \alpha+\left(x_{i t}-\hat{\theta}_{i} \overline{X_{i}}\right)^{\prime} \beta+\left\{\left(1-\hat{\theta}_{i}\right) \alpha_{i}+\left(\varepsilon_{i t}-\hat{\theta}_{i} \overline{\varepsilon_{i}}\right)\right\} \text { where } \hat{\theta}_{i} \text { is a consistent }
$$

estimate of $\theta_{i}=\sqrt{\left(\sigma_{\varepsilon}^{2} /\left(T_{i} \sigma_{\alpha}^{2}+\sigma_{\varepsilon}^{2}\right)\right.}$.

The RE estimator uses both between and within variation in the data and has special cases of pooled OLS $\left(\hat{\theta}_{i}=0\right)$ and FE $\left(\hat{\theta}_{i}=1\right)$. The RE estimator approaches the FE estimator as T (number of periods) gets large and as $\sigma_{\alpha}^{2}$ gets larger relative to $\sigma_{\varepsilon}^{2}$ because in those cases $\hat{\theta}_{i} \rightarrow 1$ (Cameron, 2010).

The empirical model that we estimate is denoted by an equation of the following form:

$$
W_{i t}=X_{i t} \beta+\beta_{1} Y_{i t}+\beta_{2} A_{i t}+\beta_{3} N E S C_{i} * A_{i t}+\beta_{4} E S C_{i} * A_{i t}+\beta_{5} T_{i}+{ }_{i} \beta_{6} T_{i} * X_{i t}+\beta_{6} T_{i} * A_{i t}+\varepsilon_{i t}
$$

where $i$ indexes individuals and $t$ represents period of time. " $\mathrm{W}_{\mathrm{it}}$ " represents the natural $\log$ of individual' household net worth at time t, " $X_{i t}$ " is a vector of covariates that includes individual and household characteristics (marital status, wealth endowment, gender, number of children in the household, state of residence, level of education) " $\mathrm{Y}_{\mathrm{it}}$ " indicates time spent in the host country since migration, " $\mathrm{A}_{\mathrm{it}}$ " is the variable reflecting the self-assessed level of assimilation, "NESC" and "ESC" are dummy variables indicating migrants from non-English 
and English speaking countries and $\mathrm{T}_{\mathrm{i}}$ is a time dummy variable that take the value of 1 if the year is 2010 and zero otherwise.

The estimate of the coefficients $\beta_{3}$ and $\beta_{4}$ will hows how the self-assessed measure of assimilation affects the wealth accumulation patterns of migrants

\section{ESTIMATION RESULTS}

The estimation shows strong evidence that there is an effect of assimilation on migrants' net worth which is positive for all individuals (natives and migrants) but significant differnces arise when we consider migrants grouped by countries of origin (ESC or NESC respectively).

The initial estimations from the pooled OLS model presented in Table confirm that migrants' wealth increases with time spend in the host country but also with the degree of satisfaction with community participation. The coefficient of this variable when migrants are from non-English speaking countries is statistically significantly different from zero and negative, implying that the more a migrant feels integrated into the host country the less $\mathrm{s} / \mathrm{he}$ accumulates wealth. This result is consistent with the possibility of lower perceived uncertainty among those migrants who self-reported a greater satisfaction with the level of integration in the community where they live.

When wealth is disaggregated as financial and non-financial, the results do not change significantly, confirming the negative and strong effect of assimilation on net worth aside from migrants from non-English speaking countries (for whom the coefficient is still negative and statistically significant but only in the case of non-financial wealth). This result may be intuitively justified because households kept as precautionary balances those assets that are safer and stable. Even when assets are relatively illiquid compared to financial assets, if migrants feel more integrated within the society, they have a lower perception of uncertainty 
along with assets kept for precautionary reasons. Kimball (1993) theory of risk-taking with multiple sources of risk provides some support to our interpretation, pointing out that some risks that are not fully insurable (for instance uncertainty derived from lack of integration in the host country) may induce risk-averse or prudent individuals to reduce/increase the portfolio of risky/non-risky assets. Guiso et al. (1996) also provide evidence of a link between the choice of portfolio and uncertainty, showing a negative correlation between background uncertainty and ownership of risky assets - in our case this is represented by the decrease of non-financial assets, as the migrants' increased integration leads to dimished feelings of uncertainty about the host country.

There are other factors that affect migrants' net worth and present statistically significant results with most of the coefficients' signs in line with the findings of the literature on wealth and also savings' theory. Time spent in the host country (YSM) is an important explanatory variable and the coefficient is positive and significant, similarly to previous cross-section studies. The region where migrants live also plays an important role in explaining net worth, especially when they are located in remote areas of Australia. The resulting coefficient shows that net worth is significantly lower for migrants and natives-born living remotely, especially in the case of financial assets.

As expected, individual disposable income is highly correlated with wealth accumulation and should be included as an explanatory variable. There is however a clear issue of endogeneity since for some individuals wealth is used as a source of income even though for the majority of people the most important source is paid work. In order to solve this issue while improving the robustness of our estimations, we ought to follow an instrumental variable (IV) approach. This is unfortunately proving unfeasible within this paper, as the factors that explain disposable income are likely to be explaining also net wealth. 
Regarding net worth, we find that individuals accumulate more when they are married, more educated and have spent more time in the host country, along with assimilation (community participation). On the other hand, if migrants are from NESC and satisfied with their degree of assimilation, they tend to accumulate less wealth, with similar results for all individuals (native-born and migrants) if they have children younger than 14 years old or they reside in some specific Australian States.

With reference to financial and non-financial assets, we find similar results for both, implying that NESC migrants accumulate less wealth as they feel more assimilated. This effect is statistically significant only in the case of non-financial assets. Even though these assets are less liquid, they may appear safer as they are less volatile than financial assets: this may explain a change in migrants' behaviour in terms of reducing the accumulation of safer assets as precautionary savings decreasing with increased feelings of assimilation in Australia.

\section{CONCLUSIONS}

The concept of assimilation of migrants is far from being totally defined since it covers so many different aspect of life, some of which remain hard to measure. We examine empirically the relationship between migrants' assimilation and their wealth accumulation patterns (savings) to establish whether or not migrants who are more assimilated are less uncertain about their socioeconomic situation so they adjust the level of savings accumulated for precautionary reasons. In addition, we evaluate how the degree of assimilation has a different effect on their savings depending if they are from English or non-English speaking countries, and whether they prefer to keep savings as financial or non-financial assets. We find that migrants who feel more assimilated tend to accumulate more wealth but when we differentiate individuals by countries of origin those coming from non-English speaking 
countries surprisingly show the opposite result. We also find that wealth in general increases as immigrants feel more satisfied with the participation in the community, which may provide a better knowledge of the new society and the opening of new opportunities to gain social capital. In the case of non-English speaking immigrants we find an opposite result. Perhaps they may find it harder to participate to community life in Australia because of language barriers. Alternatively, they may perceive their situation in the host country as less uncertain when they feel more integrated, and therefore accumulate less wealth for precautionary reasons mainly in the form of non-financial assets.

The relevance of the topic of our study stems from the fact that immigrants' savings not only constitute a major financial support for the countries of origin, but can also contribute to the pool of savings and increase the resources available for capital formation in the host country. Migrants' socioeconomic assimilation and feelings about their situation in the host country appear to be important aspects when they decide how to allocate their wealth and choose their portfolio of assets. Since migrants also have the chance to keep some of their savings in their country of origins, whether through regular remittances or just buying assets at home, it is important for host country policy makers to have a clearer picture of immigrants' participation in the domestic financial markets. Failing to do so may harm a sizeable pool of savings which is either not utilised or diverted elsewhere. This is particularly relevant for a country like Australia where net overseas migration contributes substantially to the total population growth (54\% in the 12 months to September 2011$)$ and 26.8 per cent of the estimated resident population in 2010 is made up of foreign-born.

Even though remittances and migrants' savings are seen as a substantial source of economic development for the countries of origin, there may also provide significant benefits to host countries in the form of a bigger pool of funds supplied to the local financial system to finance investments with less dependency from (perhaps more volatile) capital inflows. 


\section{APPENDIX}

\section{Table A1: Composition of migrants' household wealth - Mean values (\$000)}

\begin{tabular}{|c|c|c|c|c|c|c|c|c|c|}
\hline \multirow[b]{2}{*}{ Type of Asset/Debt (\$000) } & \multicolumn{3}{|c|}{2002} & \multicolumn{3}{|c|}{2006} & \multicolumn{3}{|c|}{2010} \\
\hline & ESC & NESC & $\begin{array}{c}\% \text { diff. } \\
\text { ESC-NESC }\end{array}$ & ESC & NESC & $\begin{array}{c}\% \text { diff. } \\
\text { ESC-NESC }\end{array}$ & ESC & NESC & $\begin{array}{c}\% \text { diff. } \\
\text { ESC-NESC }\end{array}$ \\
\hline Bank Accounts & 22.60 & 17.23 & $31.14 \%$ & 22.33 & 19.98 & $11.74 \%$ & 27.89 & 22.38 & $24.62 \%$ \\
\hline Pensions - Superannuation & 69.25 & 34.64 & $99.90 \%$ & 99.47 & 47.84 & $107.94 \%$ & 120.60 & 60.90 & $98.03 \%$ \\
\hline Equity Investments & 37.67 & 14.09 & $167.30 \%$ & 49.48 & 20.97 & $135.98 \%$ & 39.64 & 18.57 & $113.47 \%$ \\
\hline Other Assets (cash, trust funds, etc) & 9.04 & 9.60 & $-5.82 \%$ & 11.80 & 16.71 & $-29.36 \%$ & 19.17 & 12.67 & $51.25 \%$ \\
\hline Housing and other Property & 226.42 & 198.11 & $14.29 \%$ & 357.72 & 340.29 & $5.12 \%$ & 343.51 & 336.29 & $2.15 \%$ \\
\hline Vehicles & 15.20 & 10.79 & $40.88 \%$ & 15.40 & 12.31 & $25.05 \%$ & 12.92 & 13.24 & $-2.39 \%$ \\
\hline Business and Farms & 28.03 & 27.25 & $2.87 \%$ & 30.83 & 30.33 & $1.66 \%$ & 20.72 & 34.14 & $-39.29 \%$ \\
\hline TOTAL ALL FINANCIAL ASSETS & 138.56 & 75.57 & $83.36 \%$ & 183.08 & 105.50 & $73.54 \%$ & 207.30 & 114.52 & $81.01 \%$ \\
\hline TOTAL ALL NON-FINANCIAL ASSETS & 269.65 & 236.15 & $14.18 \%$ & 403.95 & 382.94 & $5.49 \%$ & 377.16 & 383.67 & $-1.70 \%$ \\
\hline TOTAL ASSETS & 408.21 & 311.72 & $30.95 \%$ & 587.03 & 488.44 & $20.19 \%$ & 584.46 & 498.19 & $17.32 \%$ \\
\hline Credit Card debts & 0.73 & 0.55 & $32.40 \%$ & 0.91 & 0.78 & $17.21 \%$ & 1.04 & 1.05 & $-1.02 \%$ \\
\hline HECS debts (student debt) & 0.62 & 1.45 & $-57.44 \%$ & 0.71 & 1.53 & $-53.51 \%$ & 0.70 & 2.02 & $-65.31 \%$ \\
\hline Housing and other Property debt & 41.31 & 41.31 & $0.00 \%$ & 58.46 & 67.76 & $-13.73 \%$ & 70.36 & 82.62 & $-14.84 \%$ \\
\hline Business debt & 5.41 & 3.16 & $70.96 \%$ & 3.91 & 3.30 & $18.47 \%$ & 2.91 & 3.28 & $-11.49 \%$ \\
\hline Other debts & 5.57 & 3.58 & $55.61 \%$ & 8.88 & 7.83 & $13.37 \%$ & 6.28 & 11.18 & $-43.82 \%$ \\
\hline TOTAL DEBTS & 53.64 & 50.06 & $7.15 \%$ & 72.87 & 81.21 & $-10.26 \%$ & 81.29 & 100.15 & $-18.83 \%$ \\
\hline NET WEALTH & 354.6 & 261.66 & $35.51 \%$ & 514.2 & 407.2 & $26.26 \%$ & 503.17 & 398.05 & $26.41 \%$ \\
\hline
\end{tabular}

Note: All values are in real terms - Deflated by the CPI serie from ABS

ESC: migrants from English-speaking countries

NESC: migrants from Non-English speaking countries 
Table A2: Pooled OLS Estimation - Dep. Variable Log of Net Wealth

\begin{tabular}{|c|c|c|c|}
\hline VARIABLES & Net Worth & Financial Assets & Non-Financial Assets \\
\hline \multirow[t]{2}{*}{ log of wealth endowment } & $0.5783^{\star \star \star}$ & 0.5650 *** & $0.5706^{\star * *}$ \\
\hline & $(0.01424)$ & $(0.01568)$ & $(0.01467)$ \\
\hline \multirow[t]{2}{*}{ NESC Migrant } & $0.4736^{\star \star \star}$ & $-0.3243^{\star \star *}$ & $0.5239 * \star \star$ \\
\hline & $(0.06968)$ & $(0.1092)$ & $(0.08923)$ \\
\hline \multirow[t]{2}{*}{ ESC Migrant } & $0.4527^{* \star *}$ & 0.1242 & $0.4057^{* \star *}$ \\
\hline & $(0.07753)$ & $(0.1049)$ & $(0.1021)$ \\
\hline \multirow[t]{2}{*}{ Male } & -0.01996 & $0.1298^{\star \star \star}$ & $-0.06778 * *$ \\
\hline & $(0.02711)$ & $(0.03855)$ & $(0.03290)$ \\
\hline \multirow[t]{2}{*}{ Years since migration } & $0.01476^{\star \star *}$ & 0.000433 & $0.008845^{\star \star *}$ \\
\hline & $(0.001407)$ & $(0.001843)$ & $(0.001661)$ \\
\hline \multirow[t]{2}{*}{$\mathrm{HH}$ with children younger than 14} & 0.04831 & $-0.2815^{\star \star *}$ & $0.2710^{* \star *}$ \\
\hline & $(0.03124)$ & $(0.04374)$ & $(0.03677)$ \\
\hline \multirow[t]{2}{*}{ Married } & $0.6672^{\star \star \star}$ & $0.8708^{\star \star \star}$ & $0.7286 * \star \star$ \\
\hline & $(0.04217)$ & $(0.05758)$ & $(0.04805)$ \\
\hline \multirow[t]{2}{*}{ Satisfied with community participation } & $0.1642^{* * *}$ & $0.1955^{\star \star \star}$ & $0.1930^{\star \star \star}$ \\
\hline & $(0.03959)$ & $(0.05601)$ & $(0.04722)$ \\
\hline \multirow[t]{2}{*}{ interaction NESC/community satisfaction } & $-0.2569 * * *$ & -0.04161 & $-0.2627^{\star * *}$ \\
\hline & $(0.08190)$ & $(0.1258)$ & $(0.1006)$ \\
\hline \multirow[t]{2}{*}{ interaction ESC/community satisfaction } & -0.1210 & -0.1435 & -0.1452 \\
\hline & $(0.08165)$ & $(0.1139)$ & $(0.1095)$ \\
\hline \multirow[t]{2}{*}{ Living in remote area } & $-0.06682^{\star}$ & $-0.3730^{\star * *}$ & 0.000918 \\
\hline & $(0.03914)$ & $(0.05708)$ & $(0.04496)$ \\
\hline \multirow[t]{2}{*}{ Constant } & $4.1225^{\star \star \star}$ & $3.5557^{* \star *}$ & $4.0718^{\star \star *}$ \\
\hline & $(0.1590)$ & $(0.1814)$ & $(0.1667)$ \\
\hline Time Dummy and Interactions & YES & YES & YES \\
\hline Observations & 12,150 & 12,416 & 12,136 \\
\hline R-squared & 0.529 & 0.375 & 0.410 \\
\hline
\end{tabular}

NESC and ESC variables : Test for linear combinations of coeficients

\begin{tabular}{lccc}
\hline \hline NESC variables (mignesc + commsatis + inescsat) & $\mathbf{0 . 3 8 0 ^ { \star \star \star }}$ & $\mathbf{- 0 . 1 7 ^ { * }}$ & $\mathbf{0 . 4 5 4 ^ { \star \star * }}$ \\
& $(0.068)$ & $(0.0969)$ & $(0.08)$ \\
ESC variables (migesc + commsatis + iescsat) & $\mathbf{0 . 4 9 5 ^ { \star \star \star }}$ & $\mathbf{0 . 1 7 6 * \star}$ & $\mathbf{0 . 4 5 3 ^ { \star \star \star }}$ \\
& $(0.575)$ & $(0.0853)$ & $(0.073)$ \\
\hline
\end{tabular}

Variables iescsat and inescsat represent the interaction of commsatis and migesc or mignesc

Robust standard errors in parentheses

*** $p<0.01,{ }^{* \star} p<0.05,{ }^{*} p<0.1$ 
Table A3: Pooled FGLS or Population Average (PA) Estimation

\begin{tabular}{|c|c|c|c|}
\hline VARIABLES & Net Worth & Financial Assets & Non-Financial Assets \\
\hline \multirow[t]{2}{*}{ log of wealth endowment } & $0.5768^{\star \star *}$ & $0.5610^{\star * *}$ & $0.5596^{\star * *}$ \\
\hline & $(0.01442)$ & $(0.01593)$ & $(0.01445)$ \\
\hline \multirow[t]{2}{*}{ NESC Migrant } & $0.4559 * * *$ & $-0.2497^{\star \star \star}$ & $0.4847^{\star \star \star}$ \\
\hline & $(0.06793)$ & $(0.09593)$ & $(0.08462)$ \\
\hline \multirow[t]{2}{*}{ ESC Migrant } & $0.4816^{\star * *}$ & $0.1610^{*}$ & $0.3890^{* * *}$ \\
\hline & $(0.07062)$ & $(0.09025)$ & $(0.09143)$ \\
\hline \multirow[t]{2}{*}{ Male } & 0.005327 & $0.1076^{\star \star *}$ & -0.04811 \\
\hline & $(0.02469)$ & $(0.03476)$ & $(0.03050)$ \\
\hline \multirow[t]{2}{*}{ Years since migration } & $0.01735^{\star \star \star}$ & $0.005153^{\star \star *}$ & $0.01281^{\star \star \star}$ \\
\hline & $(0.001378)$ & $(0.001769)$ & $(0.001610)$ \\
\hline \multirow[t]{2}{*}{$\mathrm{HH}$ with children younger than 14} & $0.06960^{* \star *}$ & $-0.1414^{\star * *}$ & $0.2651^{* \star *}$ \\
\hline & $(0.02427)$ & $(0.03137)$ & $(0.02927)$ \\
\hline \multirow[t]{2}{*}{ Married } & $0.6812^{\star * *}$ & $0.8358^{\star \star \star}$ & $0.8092^{\star \star *}$ \\
\hline & $(0.03432)$ & $(0.04484)$ & $(0.04148)$ \\
\hline \multirow[t]{2}{*}{ Satisfied with community participation } & $0.1577^{\star \star \star}$ & $0.1104^{\star \star \star}$ & $0.1838^{\star \star *}$ \\
\hline & $(0.02926)$ & $(0.03794)$ & $(0.03452)$ \\
\hline \multirow[t]{2}{*}{ interaction NESC/community satisfaction } & $-0.1494^{\star *}$ & 0.03140 & -0.1247 \\
\hline & $(0.06979)$ & $(0.09660)$ & $(0.08424)$ \\
\hline \multirow[t]{2}{*}{ interaction ESC/community satisfaction } & -0.1034 & -0.03542 & -0.07928 \\
\hline & $(0.06986)$ & $(0.08877)$ & $(0.09279)$ \\
\hline \multirow[t]{2}{*}{ Living in remote area } & -0.05750 & $-0.3494^{\star \star *}$ & 0.01698 \\
\hline & $(0.04075)$ & $(0.05469)$ & $(0.04576)$ \\
\hline \multirow[t]{2}{*}{ Constant } & $4.0263^{* \star *}$ & $3.4843^{* * *}$ & $4.0096^{* * *}$ \\
\hline & $(0.1596)$ & $(0.1793)$ & $(0.1629)$ \\
\hline \multirow{2}{*}{$\begin{array}{l}\text { Observations } \\
\text { chi2 }\end{array}$} & 12,150 & 12,416 & 12,136 \\
\hline & 3721.5 & 2560.6 & 3330.2 \\
\hline \multicolumn{4}{|c|}{ NESC and ESC variables : Test for linear combinations of coeficients } \\
\hline \multirow[t]{2}{*}{ NESC variables (mignesc + commsatis + inescsat) } & $0.464^{\star \star \star}$ & -0.107 & $0.543^{\star * *}$ \\
\hline & $(0.0567)$ & $(0.075)$ & $(0.068)$ \\
\hline \multirow[t]{2}{*}{ ESC variables (migesc + commsatis + iescsat) } & $0.535^{\star \star \star}$ & $0.235^{\star \star \star}$ & $0.493^{\star \star *}$ \\
\hline & $(0.0516)$ & $(0.070)$ & $(0.064)$ \\
\hline
\end{tabular}

Variables iescsat and inescsat represent the interaction of commsatis and migesc or mignesc

Standard errors in parentheses

*** $p<0.01,{ }^{* *} p<0.05,{ }^{*} p<0.1$ 


\section{REFERENCES}

Amuedo-Dorantes, Catalina, Pozo Susan. (2002). Precautionary Savings by Young Immigrants and Young Natives. Southern Economic, 69(1), 48 - 71.

Antecol, Heather, Kuhn Peter, Trejo Stephen. (2006). Assimilation via Price or Quantities? Sources of Immigrants earnings Growth in Australia, Canada and the United States. Journal of Human Resources, 41(4), 821-840.

Baum, Christopher F. (2006). An Introduction to Modern Econometrics using Stata. Texas 77845 USA: Stata Press.

Borjas, George. (1985). Assimilation, Changes in Cohort Quality, and the Earnings of Immigrants. Journal of Labor Economics, 3(4), 463-489.

Borjas, George. (1995). Assimilation and Changes in Cohort Quality Revisited: What Happened to Immigrants Earnings in the 1980s. Labour Economics, 13(2), 201-245.

Borjas, George. (1999). The Economic Analysis of Immigration. In Handbook of Labour Economics (Ed.), Orley Ashenfelter and David Card (Vol. 3A). Amsterdam: Elsevier Science.

Cameron, C., A. and Trivedi, P., K. (2010). Microeconometrics using Stata: Revised Edition. Texas 77845 USA: Stata Press.

Carroll, Christopher D. (1997). Buffer stock saving and the life cycle/permanent income hypothesis. Quarterly Journal of Economics, 112, 1-56.

Chiswick, Barry. (1978). The Effect of Americanization on the Earnings of Foreign-Born Men Journal of Political Economy, 86(5), 897-921.

Chiswick, Barry R., \& Miller, Paul W. (2011). Negative and Positive Assimilation, Skill Transferability, and Linguistic Distance. SSRN eLibrary. 
Cobb-Clark, Deborah A., \& Hildebrand, Vincent A. (2009). The Asset Portfolios of NativeBorn and Foreign-Born Australian Households. Economic Record, Vol. 85, Issue 268, pp. 46-59.

Djajic, Slobodan and Milbourne Ross. (1988). A General Equilibrium Model of GuestWorker Migration. Journal of International Economics, 25, 335-351.

Doiron, Denise, \& Guttmann, Rochelle. (2009). Wealth Distributions of Migrant and Australian-Born Households. Economic Record, Vol. 85, Issue 268, pp. 32-45.

Duncan, Brian, Trejo Stephen. (2008). Immigration and the US Labor Market Discussion Paper: Centre for Research and Analysis of Migration-CReAM.

Dustmann, Christian. (1997). Return Migration, Uncertainty and Precautionary Savings. . Journal of Development Economics, 52, 295 - 316.

Guiso L., Jappelli T. and Terlizzese D. (1996). Income Risk, Borrowing Constraints and Portfolio Choice. American Economic Review, American Economic Association, 86(1), 158-172.

Hatton, T., Leigh A. (2007). Immigrants Assimilate as Communities, not just as Individuals. IZA Discussion Paper, 2538.

Headey, Bruce, Warren, Diana, \& Wooden, Mark. (2005). Structure and Distribution of Household Wealth in Australia: Cohort Differences and Retirement Issues. SSRN eLibrary.

Kimball M. (1993). Standard Risk Aversion. Econometrica, 3, 589-611.

Schaeffer, Peter V. (1995). The Work Effort and the Consumption of Immigrants as a Function of Their Assimilation. International Economic Review, 36(3), 625-642.

Summerfield, M. (Ed.). (2010). HILDA User Manual - Release 10. Melbourne, Australia: Melbourne Institute of Applied Economic and Social Research - University of Melbourne. 